\title{
Why Was the Habsburg Princess Granted the Right to Rule the Kingdom of Croatia in 1712?
}

This paper presents the new interpretations of Croatian historiographers concerning the so-called Croatian Pragmatic Sanction or Article 7:1712, promulgated by the Sabor in March 1712. The Sabor's decision granted the Habsburg female line the succession right in the Kingdom of Croatia. Our focus has been on answering the question why this decision was made in 1712, instead of using the traditional interpretations of Croatian narrative historiography. The general interpretative context of this paper consists of two political trends present in the Habsburg Monarchy and the Kingdom of Croatia at the beginning of the $18^{\text {th }}$ century: the early modern state-building process and the preservation of power of the Sabor elite.

Keywords: Sabor, Croatian Pragmatic Sanction, Habsburg female succession, Lands of the Crown of Saint Stephen, $18^{\text {th }}$ century

\section{From historical rights to temporal interests}

When in the late $19^{\text {th }}$ and at the turn of the $20^{\text {th }}$ century the Croatian historians first wrote analyses of the so-called Croatian Pragmatic Sanction or Article 7: 1712, promulgated by the Croatian diet, the Sabor, in March $1712,{ }^{1}$ those analyses were all about the rights and privileges of the Croatian status et ordines. Their interpretations were largely guided by two perspectives or arguing points. The first one concerned the question on what historical right(s) the Croatian nobles based their legal and political power to declare the right of Habsburg female succession in the Kingdom of Croatia in case the male line became extinct. The

Ivana Jukić, University Department of Croatian Studies, Department of History, Borongajska cesta 83d, 10000 Zagreb, Croatia, E-mail: ijukic@hrstud.hr

1 For the text of the Article, see: Zaključci hrvatskog sabora, sv. 2 (1693-1713), ed. Josip Buturac et al. (Zagreb: Državni arhiv NR Hrvatske, 1958), Article 7, 471-472. 
second perspective was directed at explaining that all political actions taken in order to declare the right of Habsburg female rule stemmed from the political conflicts between the Hungarians and the Croatian nobility. It was all instigated by the Hungarian nobles, who attacked the rights and privileges of the Croatian nobility. ${ }^{2}$

Although a legal historical analysis of the so-called Croatian Pragmatic Sanction is important, and the existing interpretations could be complemented with some new facts and interpretative perspectives, this paper focuses on the question "why" and analyses the contemporary socio-political reasons behind the formulation of the legal decision in 1712. The main idea is that the Sabor's decision in 1712 , although based on the historical rights and privileges of the Croatian estates, was a product of the current socio-political situation and personal interests of both parties: members of the Habsburg family and the political elite within the Kingdom of Croatia. The main agenda behind it, concealed under the formula of "rights and privileges," was to preserve the power of the Sabor elite within the regional elite network in the slow, but ongoing state-building process of the Habsburg Monarchy. When we look at these two processes - state-building and the preservation of power for the Sabor elite as the main element for the regional elite - then a legal decision such as Article 7:1712 becomes a historiographic story telling us who the members of the Sabor elite were and what their domain was, as well as how they communicated with the political centre, i.e. the Court of Vienna. Thereby the most interesting part of research is recognizing their overlapping interests, where both parties could play with the regional rights and privileges in order to accomplish particular political goals.

In its first two sections, this paper aims at presenting the specific context, that is, the problems which occurred simultaneously yet independently:

a) to the members of the Habsburg family who were concerned about preserving the vision of the Habsburg Monarchy in the Danube area, and

b) to certain members of the Croatian political elite who were concerned about the preservation of the existing socio-political reality, in which the Kingdom of Croatia (i.e. Zagreb, Varaždin, and Križevci counties) was only within their or the Sabor's scope of influence.

\footnotetext{
2 For various interpretations in the Croatian historiography, see: Vjekoslav Klaić, "Hrvatska pragmatička sankcija", Rad JAZU 206 (1915); Ivan Beuc, "Kojim pravom postaje Marija Terezija hrvatskim kraljem?," Vjesnik Kraljevskog državnog arkiva 8 (1939). As for the Austrian historiography, see: Gustav Turba, Die Grundlagen der Pragmatischen Sanktion I-II (Leipzig; Vienna: F. Deuticke, 1912); Turba, Die Pragmatische Sanktion. Authentische Texte samt Erläuterungen und Übersetzungen (Vienna, 1913); Turba, Die pragmatische Sanktion - mit besonderer Rücksicht auf die Länder der Stephankrone. Neues zur Entstehung und Interpretation 1703-1744 (Vienna, 1906); Turba, Reichsgraf Seilern aus Ladenburg am Neckar 1646-1715 als kurpfälzischer und österreichischer Staatsmann (Heidelberg, 1923).
} 
These issues motivated the Court of Vienna and the regional elite to create time and space for an intense political dialogue on the succession law in the Kingdom of Croatia in 1711/1712, as a solution for both parties.

The third section analyses the course of the bargaining process between the Court of Vienna and the members of the regional elite, naming the main characters in the process, emphasising the influence of personal connections in those activities, and presenting the final result of the dialogue.

The final section poses the following question: did the Sabor elite use the political profit gained by the declaration of the so-called Croatian Pragmatic Sanction for achieving the much needed socio-political change in the Kingdom of Croatia in the decades after 1712 ?

\section{Family issues and the state-building process}

The main problem and trauma for the Habsburg family - and for the dynasty as well - was created in 1711, when Joseph I (1705-1711) died without a male successor. His brother Charles, or Charles III, who was at the time the King of Spain, and was in war with France in order to keep his Spanish legacy, was thus forced to return to Austria and take over the reins of the Empire and the Austrian Monarchy. That moment signified the end of the War of the Spanish Succession and the loss of the Spanish crown and its territories. The only territory the Habsburgs were able to keep as part of their Spanish territorial legacy were their Italian and Dutch areas. ${ }^{3}$ The main reason for such an outcome for the Austrian House was the European powers' intolerance regarding the possibility of reviving the Universal Monarchy in Europe, since it had always presented a great disturbance for the balance of power, especially in $18^{\text {th }}$-century Europe. The Spanish experience showed that Europe had entered into a more distinct phase of its political behaviour. Gradually, it was the balance of power and laws that began to shape the political map of Europe, rather than family issues. Nevertheless, the aggressive politics of the European powers still counted on the biological mishaps of royal families in order to extend their territories. ${ }^{4}$ To avoid the Spanish scenario in the Austrian Monarchy, which was not political fiction, the Habsburg family policies preferred to rely on the binding agreements between family members than on biological luck. In 1703, a family agreement between Leopold I, Joseph, and Charles was signed - Pactum mutuae successionis - showing that the Court of Vienna

For a general overview on this subject, see: John P. Spielman, Leopold I of Austria (New Brunswick, NJ: Rutgers University Press, 1977), 169-178.

4 During the $18^{\text {th }}$ century, the European powers were quite often involved in different wars of succession, such as the War of the Spanish Succession (1701-1714), the War of the Quadruple Alliance (17171720), the War of the Polish Succession (1733-1735), the War of the Austrian Succession (1740-1748), and the War of the Bavarian Succession (1778-1779). 
did not try to build its future on hopes and expectation. The main idea behind the agreement was, of course, the right of mutual succession to the Spanish and Austrian thrones between Joseph and Charles. The novelty was the right of succession for the female line, and Joseph's daughters had precedence. ${ }^{5}$ The agreement was kept secret from the European powers because there was a possibility that mutual succession might unite the Spanish and Austrian crowns under one family member, which would lead to the revival of the much-hated Universal Monarchy in Europe. On the other hand, the end of the War of the Spanish Succession made Central Europe, i.e. the Empire and the Hungarian lands, to the Habsburgs' key territories, the real base of their future power and their status as a European power. The foundation of dynastic power in these "Eastern parts" was the Habsburgs' hereditary and elective right to rule, but only for the male members of the family. The Habsburg female succession right met with serious legal obstacles in those parts, and so did the Habsburg supremacy.

In the Empire, for example, due to the Salic law, women could not be elected as empresses. In case of the Habsburg female succession, only a King-Consort could be Emperor. Marriage connections with the Empire were not a novelty for the Habsburgs. Leopold I, Joseph I, and Charles VI all married princesses from the Empire as a means to strengthen the Habsburgs' status in the Empire. ${ }^{6}$ After 1703, when the Habsburg female succession became a possible reality, the future King-Consort to the Habsburg heiress apparent, or heiress presumptive, and thus the future Emperor, had to be someone unquestionably loyal to the interests of the Habsburg family. The choice of the bridegroom depended on the ambitions and influence of his native family in the Empire and their willingness to cooperate with the Habsburgs. ${ }^{7}$

In 1711, the situation became complicated. Joseph I died and Charles VI, as the last living male member of the Habsburg family, who moreover lived in a quite unstable social environment, such as the one marking the beginning of the $18^{\text {th }}$ century, felt the pressure to make the Pactum publicly known. The Habsburg female succession was a huge legal decision, which could have been implemented only with the estates' approval. The dormant ambitions of the Empire estates and the Court of Vienna were awakened. Court and family factions were created immediately after Joseph's death: the widowed queen Amalie Wilhelmine, with

\footnotetext{
For a detailed description and analysis of the Pactum, see: Turba Grundlagen II, 136-157. For the text of the Pactum, see: Turba Grundlagen II, 372-392.

6 Teodor Athlet Heinrich Strattmann, the Court of Vienna Minister from 1683 to 1693, is regarded as the founder of this marriage policy. See Constantin Wurzbach, Biographisches Lexikon des Kaiserthums Osterreich I. (Vienna: Verlag der Universitäts-Buchdruckerei von L. C. Zamarski, 1856), 309-312.

7 Charles W. Ingrao, In Quest and Crisis: Emperor Joseph I and the Habsburg Monarchy (West Lafayette, IN: Purdue University Press, 1979), 31-77.
} 
a strong support of her native family Brunswick-Lüneburg from the Empire, on the one side, and the queen mother and regent Eleonore on the other. Their conflicts regarding the order of precedence in court ceremonies and their political connections with various court ministers and deputies created the possibility of a great crisis at the Court of Vienna. ${ }^{8}$ In order to prevent such court and family factions, which were expected to intensify following the publication of the Pactum, Charles wrote his political testament before he left Spain in September 1711, as the main document ensuring the succession order in the family.

Although inspired by the Pactum, Charles' testament ensured precedence in line of succession for his own future children, both male and female. One should also consider this decision as a means of crisis control and an expression of his royal authority. His testament remained secret for the same reason as the Pactum was until 1713, when he declared it a Pragmatic Sanction. ${ }^{9}$ So, the situation in the Empire regarding a potential female successor was serious. However, the Hungarian legal obstacle to the Habsburg female succession was far more dangerous for the process of keeping the core territories in Central Europe under the Habsburgs.

As for the Lands of the Crown of Saint Stephen, or the so called Hungarian Lands, i.e. Hungary, Croatia and Transylvania, the key legal problem for the Habsburgs was the legally valid Article 3:1687 of the common Diet of Hungary. Activation of this article meant the restoration of the right of free election of the king to the Croatian, Hungarian, and Transylvanian estates in case of extinction of the male Habsburg line. ${ }^{10}$ From the Habsburg perspective of Charles VI being the last living male member of the Habsburg family, this article presented a great political threat. In the worst-case scenario for the Habsburgs, activation of this article could create room for the election of any male or female member of the Habsburg family (if this family at all) as the future common Hungarian king. Theoretically speaking, Article 3:1687 could again start a game of thrones within the monarchy and threaten the Habsburg supremacy in the area. However, speculations about female succession had been present in the monarchical public long before $1711 .{ }^{11}$ Hungary was no different. For example, in 1706 Ferenc Rákóczi, the leader of the rebellion against the Habsburg rule in Hungary from 1705 to 1711, wrote: "For what reason does the House of Austria wish to acquire Transylvania

\footnotetext{
8 Hildegard Leitgeb, "Kaiserin Amalie Wilhemine, geb Prinzessin von Braunschweig-Lüneburg-Hannover (1673-1742), Gemahlin Kaiser Josephs I. Eine biographische Studie” (Doctoral dissertation, University of Vienna, 1984), 169; Alfred Arneth, "Eigenhändige Correspondenz des Königs Karl III. von Spanien (nachmals Kaiser Karl VI.) mit dem Obersten Kanzler des Königreiches Böhmen, Grafen Johann Wenzel Wratislaw," Archiv für Österreichische Geschichte 16 (1856): 153.

9 For a detailed description and analysis of Charles' political testament, see: Turba, Grundlagen II, 173-179.

10 "Articulus 3" in Corpus decretorum Juris Ungarici, vol. II (Budae: 1847), 65.

11 Leitgeb, "Kaiserin Amalie Wilhelmine”, 146-147.
} 
by force of arms, if not to consolidate its power, indeed, its very foundation? It is easy to see why some ministers would rather have their hands cut off than allow the country to separate. Obviously, the House of Austria anticipates a shortcoming on the male line, in which case the female line could keep Hungary bridled by way of Transylvania." 12 The reason for "keeping Hungary bridled" was the above-mentioned Article 3:1687. As a politician, Rákóczi expected the Habsburgs to apply their politics of particularism within the Hungarian lands as the main tool for obstructing the unanimity and consensus between the Hungarian, Croatian, and Transylvanian estates regarding the succession right. However, as much as the Habsburgs were afraid of the legal return of free election of the king to the Hungarian, Croatian, and Transylvanian estates, which would have undoubtedly presented the main obstacle to the Habsburg absolutism in the Hungarian lands, a part of the Hungarian political elite was afraid of any kind of destruction of St Stephan's Crown's political structure as the base of political power in the Hungarian lands within the Austrian Monarchy. So, during Charles' return trip from Spain, which lasted for nine months, his mother Eleonore ruled over the Austrian Monarchy. Well aware of all the problems regarding the succession rights within the Empire and the Hungarian Lands, she turned to the latter as the solution to the problem. However, not concerning the rights and privileges of the Transylvanian estates, as Rákóczi had expected, but to the estates in the Kingdom of Croatia. Since the right to elect the king was their municipal right, and the Sabor was the place to promulgate such a fundamental law, Regent Eleonore decided to choose some members of the Croatian estates as her partners in "bridling" Hungary regarding the female succession right. Whom to choose was not a difficult task. Croatian political community was highly conflicted at the beginning of the $18^{\text {th }}$ century, torn between different fractions, each one trying to prevail in obtaining or keeping political power on a regional level. This gave Vienna an opportunity to interfere and choose certain members of the regional elite, influential in the Sabor, as partners in solving the succession right problem. The fact that the Croatian political community as a whole "once upon a time had the right to choose their own kings and could not be forced to accept the Hungarian kings if not willing to do so"13 served as a mere instrument in a very gradual and sophisticated state-building process of the Court of Vienna in the Danube area. However, this process was underway owing to the cooperation between the political centre and the regional elite. The regional elite had its local interests and for the Sabor elite the Monarchy was just a means and a frame to keep the local

\footnotetext{
12 Ágnes R. Várkony, “The Last Decades of the Independent Principality (1660-1711),” in: History of Transylvania, Volume II. From 1606 to 1830, ed. Béla Köpeczi (New Jersey: Atlantic Research and Publication Inc., 2001-2002), htto://mek.oszk.hu/03400/03407/html/256.html (last accessed on January 5, 2018).

${ }_{13}$ Hrvoje Matković, Na vrelima hrvatske povijesti (Zagreb: Golden marketing and Tehnička knjiga 2006), 136.
} 
affairs in their own domain of influence. Every king or queen who was willing to take that into account was acceptable.

\section{Family issues and the regional elite networks}

A general historiographic conclusion or explanation of the reasons why Article 7:1712 was promulgated by the Sabor in 1712 can be found in the general Croatian-Hungarian conflict of 1708 , which marked "the beginning of a centuries-long strife" between the two political communities, which would reach its pinnacle in the second half of the $19^{\text {th }}$ century. ${ }^{14}$ However, when we return to the sources there is no strong evidence to support this thesis. The "1708 conflict" was neither general nor Croatian-Hungarian. So, what did actually happen in 1708 ?

A large dispute took place in 1708 during the session of the common Diet of Hungary in Pozsony, but only between certain members of the Croatian political elite. At the session of the Lower House, Juraj Erdődy, Gabrijel Erdődy, and Adam Keglević ${ }^{15}$ self-willingly proposed the so called "Erdődy's gravamina" without the consent of the Sabor or its representatives (nuncii), Juraj Plemić and Petar Gotal. ${ }^{16}$ The most problematic demands of Erdödy's party presented a serious limitation to the Sabor's authority: for example, the demand for the uniformity of Croatian and Hungarian laws or the reduction in the jurisdiction of the Sabor's officials, such as the Vice-Ban (also the Count of Zagreb and Križevci) and the Prothonotary from the ranks of the lesser nobles. ${ }^{17}$ Prothonotary Plemić and Vice-Ban Jelačić protested severely. Neither the king nor the common Diet of Hungary accepted "Erdődy's gravamina." The Palatine and the Ban stayed out of

14 We do not know whom to consider as the founder of this thesis, but since Klaićs interpretation of the so-called Croatian Pragmatic Sanction of 1912, it has been generally accepted among the Croatian historians. Cf. Klaić, "Hrvatska pragmatička sankcija," 75-76. However, in the historiographic work on the Pragmatic Sanction in the Hungarian historiography at the beginning of the $20^{\text {th }}$ century, there is no mention of a "general conflict" between the Croatian and the Hungarian nobility in 1708. See István Csekey, A magyar trónköröklési jog. Jogtörténelmi és közjogi tanulmány oklevélmellékletekkel (Budapest, 1917), 283-300.

15 The Erdődy brothers were landlords in both the Kingdom of Croatia and the Kingdom of Hungary and therefore enjoyed the rights and privileges of both kingdoms. Adam Keglević was at that time the Treasurer of the Kingdom of Croatia. They were called "attackers of the Croatian rights and privileges" in Hrvatske kraljevinske konferencije, sv.1 (1689.-1716.), ed. Josip Barbarić et al. (Zagreb: Arhiv Hrvatske, 1985), 279.

${ }_{16}$ Nuncii, the official representatives of the Sabor, were the only ones allowed to speak in the name of the Kingdom of Croatia at the sessions of the common Diet of Hungary; cf. Ivan Beuc, Povijest institucija državne vlasti kraljevine Hrvatske, Slavonije i Dalmacije (Zagreb: Pravni fakultet, Centar za stručno usavršavanje i suradnju s udruženim radom, 1985), 198-200.

${ }_{17}$ The text of "Erdődy's gravamina" has been published in Eugen Valdec, "Hrvatska u doba bune Franje II. Rákóczya” (Doctoral dissertation, University of Zagreb, 1943), 90-93. 
this conflict, ${ }^{18}$ but the strife between the above-mentioned personalities continued and would spread throughout the Croatian political community in the years to come. The community of the three counties under the Sabor's administration was caught in the net of these two fractions, led by the Erdödys on the one side and the Sabor's officials - especially the Prothonotary - on the other. The reason why the Erdődys insisted on their "anti-Croatian-rights" policy can be found in their socio-political ambitions, running much deeper than their influence in the Kingdom of Croatia. The Erdődy family was aspiring to become a member of the exclusive monarchical elite circle originating from the Hungarian lands, like the Pálffy or the Esterházy families. The opportunity to become one of the richest and most influential families in the Hungarian lands presented itself in 1704, when the last member of the Croatian branch of the Erdödy family died. The surviving Hungarian branch of the family inherited the hereditary title of the Counts of Varaždin and the Croatian estates. The integrated family property was a huge asset, but the estates were under two legal jurisdictions: the Croatian and the Hungarian. Already in 1889 Bidermann mentioned that some steps were taken by the Erdődy family to legally integrate the Erdődys' estate in Varaždin County with those in Hungary, in order to avoid legal subjection to the laws and jurisdiction of the Sabor. ${ }^{19}$ We have good reasons to follow Bidermann's thoughts on this matter. After 1700s, the Erdödys were constantly involved in legal disputes with different personalities in the Kingdom of Croatia. The Erdődy family also had problems with the only living member of the Croatian branch, Dora Barbara, who was married to Theodor Auersperg. She and her husband sued the Erdődys, probably over the ownership rights over a part of the Croatian estates..$^{20}$ This lawsuit seems to have been a never-ending story, and it was not the only one. Another strife, regarding the Erdődys' leasing rights on the copper mines of Samobor, shed a different light on the context of the 1708 conflict between the Erdődys and the Sabor elite. It is important to mention, however, that at the time of these court processes, Ban Ivan Pálffy was constantly absent from the Kingdom of Croatia, since he was the commander-in-chief against the Rákóczi rebellions (1703-1711). It was customary in those times for the jurisdiction to be passed on the Sabor's officials, such as the Vice-Ban or the Prothonotary: ${ }^{21}$ the very same officials whom the Erdődys attacked in 1708. So, were they attack-

\footnotetext{
18 For a detailed analysis of the 1708 conflict, see: Ivana Jukić and Josip Kasalo, "Kraljevinska prava, kraljevinska elita: primjer protonotara Jurja Plemića (1690.-1713.)", Zbornik Odsjeka za povijesne znanosti Zavoda za povijesne i društvene znanosti Hrvatske akademije znanosti i umjetnosti 34 (2016): 139-142.

19 Herman Ignaz Bidermann, Geschichte der österreichischen Gesamt-Staats-Idee 1526-1804 (Innsbruck, 1889), 242.

20 Ivana Jukić, Hrvatska pragmatička sankcija: cum Regi, tum Patriae (Doctoral dissertation, University of Zagreb, 2009), 172, n. 378.

${ }_{21}$ Beuc, Povijest institucija, 204-208.
} 
ing them as the only way of marginalizing the influence of those who were on the leading positions in the Sabor, in order to accomplish their interests in the Kingdom of Croatia? The story about the Samobor copper mines might help us answer this question.

Since 1654, the Samobor copper mines had been owned by the Auersperg family and in 1696, the Auerspergs decided to lease them. They were considering some noblemen from Styria and informed the Sabor on their plans through the Conference. ${ }^{22} \mathrm{~A}$ small group of officials recognized the notification as a great business opportunity for the Kingdom as a whole. From 1696 to 1698, some kind of preparations took place: the Sabor "hired" Michael Androka, a Croatian nobleman, to prepare the lease contract with the Auersperg and to run the business in his and their names as well. However, some members of the Sabor elite, such as Prothonotary Plemić, Vice-Ban Jelačić, etc. established the "Samobor Copper Mines Society" at the same time, with the aim of defining the contract terms between Androka and the Sabor elite. Androka soon fell into serious problems with the Auerspergs and at the end of 1698 decided to sell his leasing rights to a third party in order to pay his debt to the family. The Sabor elite wanted to be that third party and thus started collecting money to pay off the Auerspergs. However, they only succeeded to collect the down payment, which the Auerspergs declined. Instead, they gave a 50-year leasing right over the Samobor mines to the Erdödys. This was the beginning of a long-lasting dispute over the unsolved question of the main leaseholder of the Samobor copper mines. ${ }^{23}$ In this intricate net of interests, legal jurisdiction, and basically chaos, the Erdödys attempted to break the Sabor elite network by attacking the legal jurisdiction of the Sabor and those offices and officials within the Sabor whom they saw as the major obstacles to the rise of the family's economic and political power.

The crisis of 1708 showed to the Sabor elite that, if they wanted to preserve their socio-political supremacy within the Kingdom of Croatia, they needed a law which would demonstrate once and for all the legal autonomy of the Kingdom of Croatia within the Hungarian Lands and the Monarchy. The opportunity to achieve this goal presented itself in 1711/1712, when the Court of Vienna, via a member of the monarchical elite, proposed a political deal to the Sabor elite: they would get what they wanted in return for the female succession right in the Kingdom of Croatia. So, in 1712 the Sabor proclaimed Article 7:1712 and the female succession right. In return, in 1715 they had Article 120:1715 approved by the King at the common Diet of Hungary, which guaranteed legal autonomy of the Kingdom of Croatia "for all times." ${ }^{24}$ And the Erdődys? Eventually they did

\footnotetext{
22 On the Conference of the Kingdom of Croatia, see: Beuc, Povijest institucija, 195.

${ }^{23}$ For a detailed analysis of the role of the Samobor copper mines in the relations between the Erdődys and the Sabor elite, see: Jukić and Kasalo, "Kraljevinska prava", 136-139.

24 "Articulus 120", Corpus decretorum Juris Ungarici, 109.
} 
become members of the monarchical elite, but had neither a chance to become the most influential elite in the Kingdom, nor to marginalize the influence of the Sabor elite in the first half of the $18^{\text {th }}$ century. That task was left to Charles VI and Maria Theresa, as the major challenge during their state-building process in the Kingdom of Croatia.

So, who were the people from the Court of Vienna, the monarchical and the Sabor elites, who were in charge of the political deal and dialogue in 1711/1712?

\section{The mediators in crisis management}

For the Habsburgs, the creation of the monarchy meant building a state based on close collaboration between their court and the chosen members of the monarchical elite, who were well integrated in the regional elites. This "diarchy" remained the keystone of the Habsburgs' politics throughout the Monarchy. ${ }^{25}$ The Kingdom of Croatia was no exception. From the 1670s, the diarchy partner in Croatia was usually either the Ban or the Bishop of Zagreb. One of the many problems in 1708 was that no diarchy partner was physically present in Croatia as a mediator between the Habsburg Court and the regional elite. The Ban of Croatia, Ivan Pálffy, as a member of the monarchical elite, could and should have served the purpose; however, he was constantly absent from the Kingdom due to the previously mentioned role in suppressing the Rákóczi rebellion. The Bishop of Zagreb, Martin Brajković, died in June 1708. Political instability in the Kingdom of Croatia at the time of the Rákóczi rebellion (1705-1711) could present a considerable socio-political threat to the Monarchy in its Eastern parts. So, to avoid that situation, in 1708, Joseph I made a smart pro-monarchical move using his centuries-old ius patronatus in the Hungarian Lands, i.e. the right to install ecclesiastical dignitaries. He appointed Emerik Esterházy as the new bishop of Zagreb, a well-known member of the Hungarian noble family that was, besides the Pálffys, the most influential supporter of the Habsburg politics in the Hungarian lands. The new mediator between the Court of Vienna and the Croatian elite was thus successfully installed.

Emerik Esterházy's name was not a novelty in the Croatian political community. He had already lived in Remete near Zagreb as member of the Pauline Order. In 1701, he even became the head of the order. The new bishop was also well ac-

${ }_{25}$ For an overview of the term "diarchy", see Thomas Winkelbauer, "Krise der Aristokratie? Zum Strukturwandel des Adels in den böhmischen und niederösterreichischen Ländern im 16. und 17. Jahrhundert", Mitteilungen des Instituts für österreichische Geschichtsforschung 100 (1992): 329; Jeroen Duindam, Myths of Power: Norbert Elias and the Early Modern European Court (Amsterdam: Amsterdam University Press 1994), 66-74. 
quainted with the socio-political situation in the Kingdom of Croatia. ${ }^{26}$ His role as the Bishop of Zagreb was of great political importance, because in the times when the Ban was absent, presidency over the Sabor was transferred to the Bishop of Zagreb as the locumtenens banalis. At first, Bishop Esterházy was not well accepted among the Sabor elite, but very soon his socio-political conduct proved that he was well prepared for the new role. His infiltration in the regional elite started in the Sabor and among the Sabor's officials, whom he chose as prime partners in regulating political life in the Kingdom of Croatia. His most confidential partner was Prothonotary Plemić, although according to Patačićs diary, in 1708 Esterházy did not have his support in the election for the new bishop of Zagreb. Also, the Prothonotary was not on good terms with the Ban of Croatia, Ivan Pálffy, who was a close confidant and friend of Bishop Esterházy. ${ }^{27}$ However, the new bishop was well aware of who controlled the Sabor and who was the most influential political figure among the Sabor elite. So, the Bishop's influence as the head of the Sabor during Ban Pálffy's absence was highly dependent on the help of the Prothonotary. Even his colleague, chosen to deal with the military matters in the Ban's name, the banalis locumentatis in militaris Petar Keglević, although respected in the Sabor, had little control over their actions. ${ }^{28}$ Esterházy did not stop his infiltration process into the Sabor elite. The Bishop's other partners were members of the nobility, since they were not at that moment in the position to become members of the monarchical elite, such as Count Ivan Drašković or Franjo Delišimunović. However, they were well integrated in the Sabor elites. Esterházy also communicated with the Erdődys, yet stayed out of their circle and actions. ${ }^{29}$ Although he recognized at once where the real power lay and whom to choose as partners to restore balance in Croatian political life, he did not have a solution to the problem of how to restore at least an illusion of political balance within the Kingdom of Croatia. An opportunity for that appeared unexpectedly at the end of 1711, when Regent Eleonore invited the Bishop to come urgently to Vienna to discuss a subject that was very important to His Majesty, Charles VI, and would benefit the common Hungarian Kingdom as well. ${ }^{30}$

\footnotetext{
${ }^{26}$ For additional biographical information on Emerik Esterházy, see Ivana Jukić, "Istražni postupak zagrebačkog biskupa Emerika Esterházya godine 1708. - poimanje suvremenika o biskupovoj osobnosti i slika stanja biskupije", Povijesni prilozi 23 (2004), br. 26: 136-140.

27 Ivan Kukuljević-Sakcinski, “Zapisci barona Baltazara Patačića i grofa Adama Oršića od god. 16911814.”, Arkiv za povjestnicu jugoslavensku 10 (1869): 235-237.

${ }_{28}$ For additional details on Petar Keglević, see: Ivana Jukić, “Zagrebački biskup Emerik Esterházy i čl. 7./Hrvatska pragmatička sankcija iz 1712.” (MA thesis, University of Zagreb, 2005), 116-128.

29 This conclusion has been reached based on the research and analysis of the letters kept at the Archdiocesan Archive in Zagreb, Epistolae ad episcopos, vol. 54-58; cf. Klaić, "Hrvatska pragmatička sankcija", 65-73.

30 The letter has been published in Ivana Jukić, "Vladavina žena na Bečkom dvoru 1711./1712. i Hrvatska pragmatička sankcija”, Povijesni prilozi 24 (2006), br. 30: 125-126.
} 
The Queen mother, Eleonore, acted as the regent of the Monarchy in Charles' name from April 1711 until March 1712, during the time of his return journey from Barcelona to Vienna. Judging by their correspondence and the correspondence of the court minister Wratislaw with Charles, it became obvious that the King planned to rule the Hungarian lands "in the same manner" as the other parts of his Austrian Monarchy. Eleonore knew it would be a political suicide, especially on the eve of the publication of Charles' last will, and expected a political dialogue between Charles and the Lands of the Crown of Saint Stephen on the female succession right matter. Unlike her son, she understood the socio-political habits of the Hungarian Lands much better. ${ }^{31}$ The most dangerous political scenario for the Habsburgs was firm unanimity in all the three Hungarian Lands regarding Article 3:1687. As I have mentioned before, the Hungarian political public feared that Vienna might use the rights and privileges of the Transylvanian nobility as a way of sabotaging or bridling this pre-assumed unanimity. ${ }^{32}$ However, Eleonore did not choose to use the rights and privileges of the Transylvanian nobility to control the power of Article 3:1687; instead, she chose the Croatian nobility. What inspired her to do so? There are several explanations to this. Firstly, it was a custom, before a new diet was summoned in Pozsony, for the ruler or their confidants to read the scripts and diaries of the previous ones as the guidelines and preparation work for the upcoming session. ${ }^{33}$ The diet summoned in April 1712 was a continuation of the session of 1708 and a significant episode was recorded in its diary: an attack on the rights of the Kingdom of Croatia and a great conflict between the two factions of the Croatian nobility. ${ }^{34}$ Did this give her an idea and a chance for arbitration? Secondly, the Bishop of Zagreb was a member of the Esterházy family. This family had played a major role in the recognition of the Habsburg hereditary right in the Lands of the Crown of Saint Stephen in 1687, especially due to the intercession of Emerik's uncle, Palatine Pal Esterházy. It can be assumed that Eleonore may have communicated about sensitive matters, such as the female succession right, with a member of such a family. Thirdly, the personal physician of Regent Eleonore in 1679 was Ivan Krstitelj Alpuno, whose medical career began in the Kingdom of Croatia, so he may have been the source of information regarding the socio-political situation in

\footnotetext{
31 Jukić, "Vladavina žena", 110-114.

32 See n. 12.

${ }_{33}$ Petr Mat'a, "Landstände und Landtage in den böhmischen und österreichischen Ländern (16201740). Von der Niedergangsgeschichte zur Interaktionsanalyse", in: Die Habsburgermonarchie 1620 bis 1740, Leistungen und Grenzen des Absolutismusparadigmas, ed. Thomas Winkelbauer and Petr Mat'a (Stuttgart: Franz Steiner Verlag, 2006), 364.

${ }^{34}$ National and University Library Zagreb, Acta et diaria diaetarum regni Hungariae ab anno 1708 ad annum 1765 celebratum, R 3198/3, 67-86.
} 
Croatia. ${ }^{35}$ Whatever motivated her to initiate the communication with the Bishop of Zagreb and to use the rights and privileges of the Croatian status et ordines to monarchical benefit, she instigated it on November 17, 1711 by sending an invitation letter to Bishop Esterházy. The Bishop travelled to Vienna and the rest is history (or mystery?). ${ }^{36}$

What we do know is that upon his return to Zagreb, between February and March 1712, the Bishop shared the idea of the Habsburg female succession right with several confidential and influential people, such as Prothonotary Plemić, Petar Keglević, and Baltazar Patačić. ${ }^{37}$ It seems that most of them were sceptical. However, on March 9, 1712, after Prothonotary Plemić gave a very convincing speech regarding the Croatian rights and privileges, the Sabor declared the right of the Habsburg female rule over Croatia. ${ }^{38}$

This decision was a gem, set and match for the Habsburgs against the pre-assumed firm unanimity of the Hungarian lands, i.e. Hungary, Croatia, and Transylvania regarding Article 3:1687. However, this political dialogue with the Sabor elite in 1711/1712 was just one additional step in building the Habsburgs' particularistic politics in the Lands of the Crown of Saint Stephen. After 1687, the ruler was no longer just a binding element in that political structure, but the creator of its character as well. The disintegration of the Lands of the Crown of Saint Stephen was not the goal; instead, the particularistic politics was a means to establish the ruler's supremacy. Firstly, in 1691, Leopold I declared the Diploma Leopoldinum to the Transylvanian nobility, granting them an autonomous status in the Hungarian lands and a direct line for political dialogues with Vienna. After the Sabor's decision in March 1712, and after Charles VI confirmed Article 120:1715, the same status was granted to the Kingdom of Croatia. However, in order to continue the policy of compromise and to calm down the restless political spirits in Hungary who were expecting a complete dissolution of the political structure of St Stephen's Crown, in 1715 Charles VI confirmed Article 3:1715, which prevented such dissolution. ${ }^{39}$ There were no objections from Croatia or Transylvania as neither of them had a problem with being a part of the Crown as long as their autonomy was safeguarded by the abovementioned legal decisions. When in 1722 the Habsburg female succession right was on schedule at the common Diet of Hungary, the entire Hungarian political community unanimously and unconditionally accepted the female succession right. However, the Court of Vienna had the upper hand once again. This time, the demand for the legal indivisibility of

35 Biserka Belicza, "Medicina i zdravstvo", in: Hrvatska i Europa. Kultura, znanost i umjetnost. Svezak III. Barok i prosvjetiteljstvo (XVII-XVIII. stoljeće), ed. Ivan Golub (Zagreb: Školska knjiga, 2003), 380.

36 See n. 30 .

37 Ivana Jukić, “Zagrebački biskup Emerik Esterházy”, 108-136.

38 For the text of the speech, see Klaić, "Hrvatska pragmatička sankcija”, 79-81.

39 "Articulus 3", Corpus decretorum Juris Ungarici, 78-79. 
the Lands of the Crown of Saint Stephan, first postulated in Article 3:1715, was supplemented with a new condition: the indivisibility of the Lands of the Crown of Saint Stephan was for all times conditioned upon their inseparability from the Monarchy. Breaking up with the Monarchy meant breaking the laws in Articles 2:1723 and 3:1723.40

Therefore, the Sabor's decision of 1712 played a significant role in keeping Hungary "bridled" regarding the female succession right. Did the Croatian status et ordines use this political deal to strengthen their position or role in the Austrian Monarchy?

\section{Legacy of Article 7:1712 - An opportunity missed?}

The demands of the Croatian status et ordines in 1712 were not modest if we analyse them in the context of the state-building process. Luckily for historians, those demands were written down by Bishop Esterházy in a letter he sent in May 1712 to Court Minister Johann Friedrich von Seilern, in the form of an appeal to the Minister to grant an audience to Prothonotary Plemić. The letter was a sort of information sheet for Seilern, filled with facts that would be presented to him by the Prothonotary as the demands of the Croatian status et ordines in return for the acceptance of the Habsburg female succession in the Kingdom of Croatia. Those demands were summarized by the bishop and are given here in six points:

1) The public announcement regarding the Croatian taxes, which were accepted in compliance with the king's will;

2) The Varaždin Generalate was to be preserved;

3) However, under the jurisdiction of the Sabor;

4) The Sabor's right to name the Vice-Ban;

5) The jurisdiction was to remain in the Kingdom and in the Ban's hands;

6) All laws passed in the Sabor were to be re-examined and confirmed by the king. ${ }^{41}$

Vienna accepted everything except for the demand regarding the Varaždin Generalate. Strengthening the military power of the regional elite was a bit too much to allow in the process of building an early modern European state. ${ }^{42}$ However,

\footnotetext{
40 "Articulus 2" and "Articulus 3", Corpus decretorum Juris Ungarici, 118-119.

41 The letter was published in Turba, Reichsgraf Seilern, 326, n. 1164.

42 From 1702 onwards, the Croatian estates communicated intensively with the Court of Vienna regarding the question of returning the Varaždin Generalate under the jurisdiction of the Sabor. For details see: Lidija Cerić, "Varaždinski generalat u službi apsolutističkih težnji Bečkoga dvora", Povijesni prilozi 28 (2009), br. 36: 118-125.
} 
all legal, administrative, and judicial power in the three counties and the Banate Border remained in the hands of the Sabor. This was political success with a great potential to start the unavoidable socio-political integration in the Monarchy on Croatia's own terms, at its own pace, and for it to be regarded as a regional initiative. However, this opportunity was missed. When in 1755 a massive peasant rebellion broke out in Croatia, the passive, counterproductive, and malcontent behaviour of the Sabor elite came to the surface. Maria Theresa summoned a commission to investigate the causes of the rebellion, with Count Michael Althan as its head. As the key problems in Banate Croatia he pointed out the following: the accumulation of political power in the hands of a few officials, the inefficiency of the Sabor, and the lack of respect for the King's or Ban's authority. ${ }^{43}$ All the conclusions revealed the presence of forces that were highly destructive for the state-building process and for Maria Theresa's reforms. From then on, the political decisions of the Court of Vienna were directed towards the exclusion of the Sabor and its elite from any administrative business.

The opportunity for the Sabor elite to use the political potential created by the 1712 political deal in order to initiate socio-political changes in central Croatia and become the co-creators of high politics in long term was lost. However, poor daily politics could not destroy the best legacy of the 1712-1715 generation of the Sabor elite: Article 120:1715, i.e. legal autonomy. Perhaps this was the highest possible achievement of this regional elite in the art of politics influenced by the early modern state-building process.

\footnotetext{
${ }_{43}$ Ivana Horbec, "Razvoj uprave i javnih službi Banske Hrvatske u vrijeme vladavine Marije Terezije" (Doctoral dissertation, University of Zagreb, 2009), 153.
} 


\section{Bibliography}

\section{Archives}

Croatia - National and University Library Zagreb - Acta et diaria diaetarum regni Hungariae ab anno 1708 ad annum 1765 celebratum, R 3198/3,

Croatia - Archdiocesan Archive in Zagreb - Epistolae ad episcopos, vol. 54-58.

\section{Published sources and literature}

Arneth, Alfred. "Eigenhändige Correspondenz des Königs Karl III. von Spanien (nachmals Kaiser Karl VI.) mit dem Obersten Kanzler des Königreiches Böhmen, Grafen Johann Wenzel Wratislaw". Archiv für Österreichische Geschichte 16 (1856).

Barbarić, Josip et al., ed. Hrvatske kraljevinske konferencije, vol. 1 (1689-1716). Zagreb: Arhiv Hrvatske, 1985.

Belicza, Biserka. "Medicina i zdravstvo". In: Hrvatska i Europa. Kultura, znanost i umjetnost. Svezak III. Barok i prosvjetiteljstvo (XVII-XVIII. stoljeće), ed. Ivan Golub, 379-403. Zagreb: Školska knjiga, 2003.

Beuc, Ivan. “Kojim pravom postaje Marija Terezija hrvatskim kraljem?”. Vjesnik Kraljevskog državnog arkiva 8 (1939): 61-121.

Beuc, Ivan. Povijest institucija državne vlasti kraljevine Hrvatske, Slavonije $i$ Dalmacije. Zagreb: Pravni fakultet: Centar za stručno usavršavanje i suradnju s udruženim radom, 1985.

Bidermann, Herman Ignaz. Geschichte der österreichischen Gesamt-Staats-Idee 1526-1804. Innsbruck, 1889.

Buturac, Josip et al., ed. Zaključci hrvatskog sabora, sv. 2 (1693-1713). Zagreb: Državni arhiv NR Hrvatske, 1958.

Cerić, Lidija. "Varaždinski generalat u službi apsolutističkih težnji Bečkoga Dvora," Povijesni prilozi 28 (2009), br. 36: 109-127.

Csekey, István. A magyar trónköröklési jog. Jogtörténelmi és közjogi tanulmány oklevélmellékletekkel. Budapest, 1917.

Corpus decretorum Juris Ungarici, vol. II. Budae, 1847.

Duindam, Jeroen. Myths of Power: Norbert Elias and the Early Modern European Court. Amsterdam: Amsterdam University Press, 1994.

Horbec, Ivana. "Razvoj uprave i javnih službi Banske Hrvatske u vrijeme vladavine Marije Terezije”. Doctoral dissertation, University of Zagreb, 2009. 
Ingrao, Charles W. In Quest and Crisis: Emperor Joseph I and the Habsburg Monarchy. West Lafayette, IN: Purdue University Press, 1979.

Jukić, Ivana. "Istražni postupak zagrebačkog biskupa Emerika Esterházya godine 1708. - poimanje suvremenika o biskupovoj osobnosti i slika stanja biskupije”. Povijesni prilozi 23 (2004), br. 26: 135-157.

Jukić, Ivana. "Zagrebački biskup Emerik Esterházy i čl. 7./Hrvatska pragmatička sankcija iz 1712.”. MA thesis, University of Zagreb, 2005.

Jukić, Ivana. "Vladavina žena na Bečkom dvoru 1711./1712. i Hrvatska pragmatička sankcija”. Povijesni prilozi 24 (2006), br. 30: 103-127.

Jukić, Ivana. "Hrvatska pragmatička sankcija: cum Regi, tum Patriae". Doctoral dissertation, University of Zagreb, 2009.

Jukić, Ivana; Josip Kasalo. "Kraljevinska prava, kraljevinska elita: primjer protonotara Jurja Plemića (1690.-1713.)”. Zbornik Odsjeka za povijesne znanosti Zavoda za povijesne i društvene znanosti Hrvatske akademije znanosti i umjetnosti 34 (2016): 125-146.

Klaić, Vjekoslav. "Hrvatska pragmatička sankcija”. Rad JAZU 206 (1915): 62-135.

Kukuljević-Sakcinski, Ivan, ed. "Zapisci barona Baltazara Patačića i grofa Adama Oršića od god. 1691-1814”. Arkiv za povjestnicu jugoslavensku 10 (1869): 225244.

Leitgeb, Hildegard. "Kaiserin Amalie Wilhemine, geb Prinzessin von Braunschweig-Lüneburg-Hannover (1673-1742), Gemahlin Kaiser Josephs I. Eine biographische Studie". Doctoral dissertation, University of Vienna, 1984.

Mat'a, Petr. "Landstände und Landtage in den böhmischen und österreichischen Ländern (1620-1740). Von der Niedergangsgeschichte zur Interaktionsanalyse”. In: Die Habsburgermonarchie 1620 bis 1740, Leistungen und Grenzen des Absolutismusparadigmas, ed. Thomas Winkelbauer and Petr Mat'a, 345-400. Stuttgart: Franz Steiner Verlag, 2006.

Matković, Hrvoje. Na vrelima hrvatske povijesti. Zagreb: Golden marketing and Tehnička knjiga, 2006.

Spielman, John P. Leopold I of Austria. New Brunswick, NJ: Rutgers University Press, 1977.

Turba, Gustav. Die pragmatische Sanktion - mit besonderer Rücksicht auf die Länder der Stephankrone. Neues zur Entstehung und Interpretation 1703-1744. Vienna, 1906.

Turba, Gustav. Die Grundlagen der Pragmatischen Sanktion I-II. Leipzig; Vienna: F. Deuticke, 1912. 
Turba, Gustav. Die Pragmatische Sanktion. Autentische Texte samt Erläuterungen und Übersetzungen. Vienna, 1913.

Turba, Gustav. Reichsgraf Seilern aus Ladenburg am Neckar 1646-1715 als kurpfälzischer und österreichischer Staatsmann. Heidelberg: C. Winter, 1923.

Valdec, Eugen. "Hrvatska u doba bune Franje II. Rákóczya”. Doctoral dissertation, University of Zagreb, 1943.

Várkony, Ágnes R. “The Last Decades of the Independent Principality (16601711)". In: History of Transylvania, Volume II. From 1606 to 1830, ed. Béla Köpeczi. New Jersey: Atlantic Research and Publication Inc, 2001-2002. http://mek. oszk.hu/03400/03407/html/256.html (last accessed on January 5, 2018).

Winkelbauer, Thomas. "Krise der Aristokratie? Zum Strukturwandel des Adels in den böhmischen und niederösterreichischen Ländern im 16. und 17. Jahrhundert". Mitteilungen des Instituts für österreichische Geschichtsforschung 100 (1992): 328-353.

Wurzbach, Constantin. Biographisches Lexikon des Kaiserthums Osterreich I. Vienna: Verlag der Universitäts-Buchdruckerei von L. C. Zamarski, 1856. 
Ivana Jukić*

\section{Zašto je habsburškoj princezi odobreno pravo vladanja Hrvatskim Kraljevstvom 1712. godine?}

\section{Sažetak}

U radu se iznose nova tumačenja hrvatskih povjesničara o tzv. Hrvatskoj pragmatičkoj sankciji ili članku 7. odluka Hrvatskog sabora donesenom u ožujku 1712. godine, kojime se odobrava ženskoj liniji dinastije Habsburg pravo na nasljeđivanje u Hrvatskom Kraljevstvu. Umjesto korištenja tradicionalnih tumačenja ove odluke, kakvu je donosila hrvatska narativna historiografija, autorica težište stavlja na pitanje zašto je odluka donesena upravo 1712. godine. Pri tome se opći, interpretativni kontekst istraživanja sastoji od prikaza i analize ranomodernog procesa izgradnje države s jedne i očuvanja moći saborske elite $\mathrm{s}$ druge strane, kao dva najznačajnija politička kretanja prisutna $\mathrm{u}$ Habsburškoj Monarhiji i Kraljevini Hrvatskoj početkom 18. stoljeća.

Ključne riječi: Sabor, Hrvatska pragmatična sankcija, nasljeđivanje dinastije Habsburg po ženskoj liniji, zemlje krune Sv. Stjepana, 18. stoljeće

* Ivana Jukić, Hrvatski studiji, Odsjek za povijest, Borongajska cesta 83d, 10000 Zagreb, Republika Hrvatska, E-mail adresa: ijukic@hrstud.hr 